\section{Stand Survival, Establishment, and Yield of a Diploid and a Triploid Watermelon Transplants of Different Ages and Sizes}

\author{
John R. Duval ${ }^{1}$ and \\ D. Scott NeSmith ${ }^{2}$
}

\begin{abstract}
Additional index words. Citrullus lanatus, seedless watermelon, stand establishment, seedlings, cell volume, transplant age
\end{abstract}

\begin{abstract}
Summary. Age and cell size can have various effects on subsequent transplant production. The interaction of the two have not been studied in triploid watermelon [Citrullus lanatus (Thunb.) Matsum \& Nakai]. Seedless watermelon production is costly due to high seed prices, therefore it is necessary to optimize transplant performance in the field, and it is often thought that triploid watermelons are less hardy than their diploid counterparts. A $3 \times 3$ factorial design was established for 2 years to determine the effects of cell sizes $1.5,3.4$, and 7.9 inch $^{3}\left(25,56\right.$, and $\left.130 \mathrm{~cm}^{3}\right)$ and transplant age $(4,6$, and 8 weeks) on the triploid watermelon 'Genesis'. The diploid cultivar 'Ferrari' was also planted for comparison. Seedling survival was affected by transplant age in 1997, and by cell size in 1998. Early main vine growth showed significant interaction between transplant age and cell size, with older transplants grown in the largest cells producing the longest vines. Early
\end{abstract}

Department of Horticulture, Georgia Experiment Station, University of Georgia, Griffin, GA 30223

A contribution of the Univ. of Georgia Agr. Expt. Sta Georgia Station, Griffin. This research was supported by state and Hatch Act funds allocated to the Georgia Agricultural Experiment Station. The cost of publish ing this paper was defrayed in part by the payment of page charges. Under postal regulations, this paper therefore must be hereby marked advertisement solely to indicate this fact.

${ }^{1}$ Graduate student.

${ }^{2}$ Associate professor yield of 6-week-old transplants of 'Genesis' was higher than 4- or 8week-old transplants in 1997. Eightweek-old transplants of 'Ferrari' outperformed younger transplants in 1997 and 1998. Results show that 'Genesis' triploid watermelon transplants could be handled similarly to the diploid 'Ferrari' without consequence.

$\mathrm{T}$ riploid watermelon transplant production is extremely costly. Seed costs are roughly six times higher for triploid than for diploid hybrids (Maynard 1997). Furthermore, germination and emergence of quality transplants are often a problem for triploid transplant producers, who want to optimize their return on investment for producing the crop. Triploid watermelons are often viewed as weak or delicate when compared to diploids. Little research comparing the two has been reported. Research examining stand establishment of triploid watermelon is needed, to ensure growers maximize their stands and fruit production of this costly crop.

Effects of transplant age and size of container in which the transplant is produced have been studied for diploid watermelon (Maynard 1997). Transplant container volume has shown mixed results on final yield of watermelon. Hall (1989) showed greater yield and early vine growth for watermelon transplants grown in 2.4 inch $^{3}\left(40 \mathrm{~cm}^{3}\right)$ cells as compared to 1.2 inch $^{3}\left(19 \mathrm{~cm}^{3}\right)$. Vavrina et al. (1993) reported no differences among transplants grown in $1.2,1.9$, and 4.0 inch $^{3}$ $\left(19,31\right.$ and $\left.66 \mathrm{~cm}^{3}\right)$ cells. Liu and Latimer (1995) demonstrated a linear increase of yield in cell volumes ranging from 1.1 to 4.9 inch $^{3}$ ( 18 to 80 $\mathrm{cm}^{3}$ ) in volume. Each of these investigators used diploid watermelon cultivars. Age of watermelon transplants has shown no effects on yield with age differences as great as 10 weeks between transplants (Vavrina et al., 1993). Similar findings were reported for other cucurbit crops (NeSmith, 1993, 1994). However, influence of transplant age on triploid watermelon yield has not been investigated.

Increasing transplant age may compound problems related to container size and the interaction of the two needs to be addressed (NeSmith and Duval, 1998). This interaction has been reported for various crucifers (Damato et al., 1994; Jones et al., 1991; Kratky et al., 1982; Olson and Locascio, 1990) and some solanaceous crops (Harmon et al. 1991; Liptay, 1987; Vavrina and Armbrester, 1991; Weston, 1988). No interaction of transplant cell volume and transplant age was reported by Vavrina et al. (1993) using a diploid cultivar of watermelon, however no data exist for triploid watermelons. By optimizing transplant age and cell volume financial returns to the growers can be maximized. This research was undertaken to determine the effect transplant cell size and age had on performance of a triploid watermelon as compared to a standard diploid cultivar.

\section{Materials and methods}

Seeds of the diploid 'Ferrari' and the triploid 'Genesis' were planted in flats filled with Metro-Mix 300 (Scotts Co., Marysville, Ohio) with cell volumes of 1.5, 3.4, and 7.9 inch $^{3}(25$, 56 , and $130 \mathrm{~cm}^{3}$ ). Two and 4 weeks later the process was repeated so that at planting, 4-, 6-, and 8-week-old transplants (from seeding date) grown in each volume of media were ready for transplanting. Emergence data was taken for each set of transplants 2 weeks after seeding in the greenhouse. 'Ferrari' was chosen as the pollinizer for 'Genesis' due to striking differences in appearance of fruit between the two. All transplants were grown in a greenhouse with day/night temperatures of $84 / 70{ }^{\circ} \mathrm{F}\left(29 / 21^{\circ} \mathrm{C}\right)$ respectively. Transplants were fertilized twice weekly with $400 \mathrm{ppm}\left(\mathrm{mg} \cdot \mathrm{L}^{-1}\right)$ soluble $20 \mathrm{~N}-8.7 \mathrm{P}-16.6 \mathrm{~K}$ fertilizer.

For the field planting, a randomized $3 \times 3$ factorial design for either cultivar was established. The blocks were merged so that 'Ferrari' and 'Genesis' rows alternated. This was done to ensure adequate pollination for the triploid watermelon 'Genesis'. Treatment combinations were replicated four times. Transplants were hand planted on 21 May 1997 and 28 May 1998. In-row spacing between plants was $4 \mathrm{ft}(1.2 \mathrm{~m})$, and rows were spaced $5 \mathrm{ft}(1.5 \mathrm{~m})$ apart. Fifteen plants were used for each treatment combination. Weed control was accomplished by cultivation and hand weeding. Water was supplied with overhead irrigation to supplement rainfall. Preplant fertilizer $(10 \mathrm{~N}-4.3 \mathrm{P}-8.3 \mathrm{~K})$ was applied at a rate of $500 \mathrm{lb} /$ acre $\left(560 \mathrm{~kg} \cdot \mathrm{ha}^{-1}\right)$. 


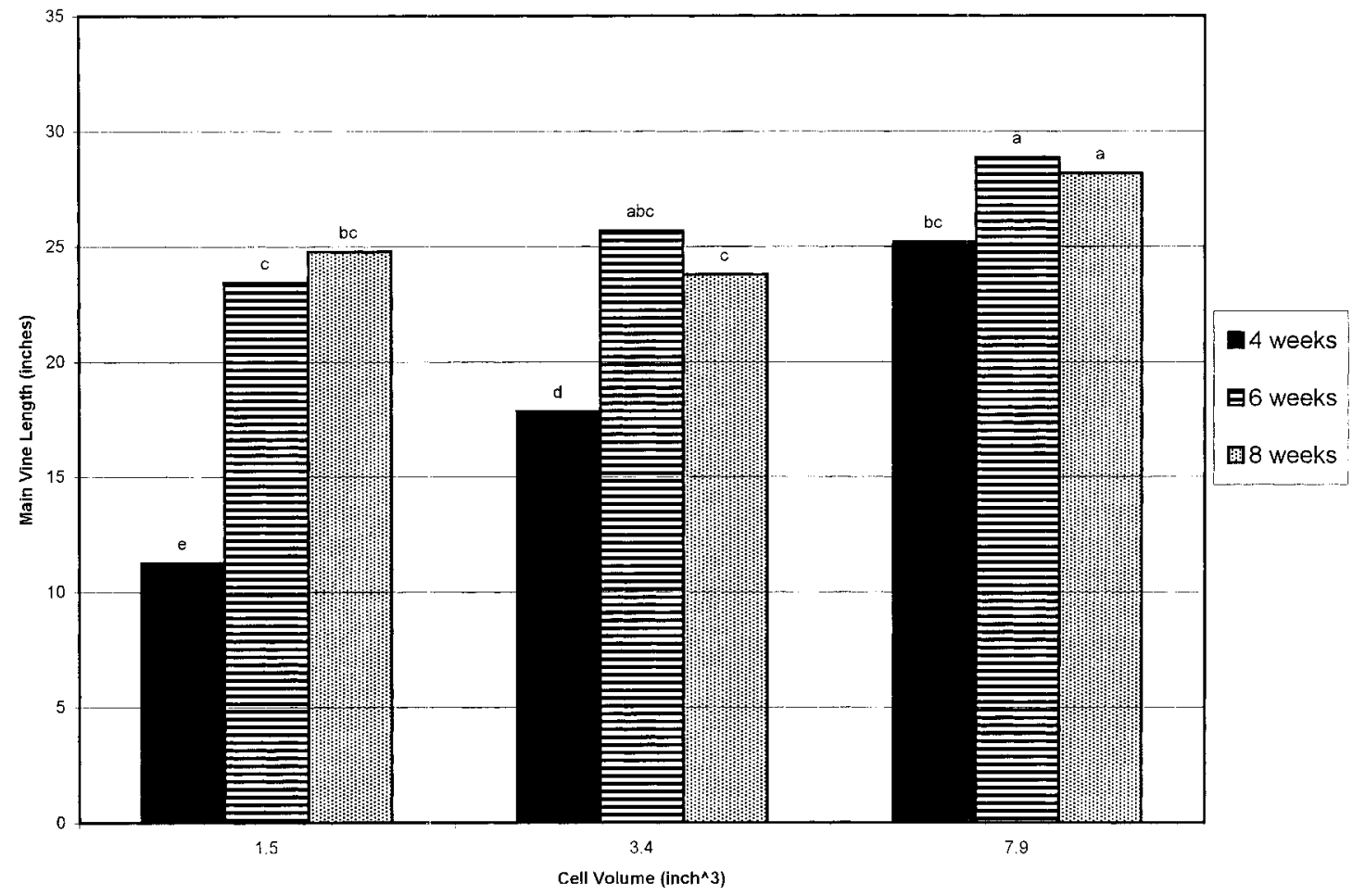

Fig. 1. Main vine length of 'Genesis' watermelon plants $42 \mathrm{~d}$ after transplanting from cell volumes of 1.5 , 3.4 , and 7.9 inch $^{3}(25,56$, and 130 $\mathrm{cm}^{3}$ ) and ages of 4,6 , and 8 weeks; $2.54 \mathrm{~cm}=1.0$ inch.

Plants were side dressed after $42 \mathrm{~d}$ with $60 \mathrm{lb} /$ acre $\left(67 \mathrm{~kg} \cdot \mathrm{ha}^{-1}\right)$ of N. Native bee populations were relied upon to provide pollination. An insect and disease control program was instituted in accordance with Georgia Cooperative Extension guidelines.

Four weeks after transplanting stand loss was evaluated. Watermelon main vine length was measured 6 weeks after planting. Harvest began on 4 Aug. 1997 and 29 July 1998; subsequent harvests occurred 1 and 2 weeks later both years. Melons in the area $5 \mathrm{ft}$ $(1.5 \mathrm{~m})$ to each side of the center of a treatment row were harvested for that variety and treatment combination. Number of watermelons and individual watermelon weights were taken for each plot. Three fruit were sampled for each treatment combination to measure soluble solids and incidence of hollow heart. Data were analyzed for each cultivar except data for transplant survival, using analysis of variance procedures (SAS Institute, 1990).

\section{Results and discussion}

Greenhouse emergence for 'Ferrari' was not affected by cell size with $98 \%$ of seeds emerging and producing viable transplants. Cell size did not influence emergence of 'Genesis' at the $(P \leq 0.05)$ level; however, there was a trend $(P \leq 0.07)$ for the smallest cell size to produce fewer viable 'Genesis' transplants. This trend may have great importance to transplant producers. An average of $73 \%$ of seeds emerged from 7.9- and 3.4-inch ${ }^{3}$ (130and $\left.56-\mathrm{cm}^{3}\right)$ cells as compared to $59 \%$ in $1.5-$ inch $^{3}\left(25-\mathrm{cm}^{3}\right)$ cells.

Field stand loss data for 1997 and 1998 revealed no difference in transplant survival between cultivars (data not shown). However, differences occurred in 1997 among ages, with 6week-old transplants having $99 \%$ survival, compared to an average of $93 \%$ for 4- and 8-week-old transplants (data not shown). In 1998, cell size affected plant survival with 1.5 inch $^{3}\left(25 \mathrm{~cm}^{3}\right)$ transplants losing $9 \%$ of their stand as compared to only $4 \%$ loss for the two other cell sizes. There were no significant interactions between cell size and transplant age for stand loss. These data indicate that 'Genesis' is equal in transplant survivability to 'Ferrari' watermelon transplants, and can be handled similarly at transplanting.

'Genesis' main vine length was affected by the interaction of transplant age and cell size in 1997 (Fig 1).
Four-week-old transplants had significantly shorter vines than older transplants grown in the same volume cells. Vines of plants grown in 7.9 -inch ${ }^{3}$ cells also were significantly longer than transplants of the same age grown in smaller cell volumes. Similar results were obtained for 'Ferrari'. Our results indicate that more rapid ground cover can be achieved using older transplants grown in larger cells. However, increased early vine growth does not necessarily translate into increased yields (Hall, 1989).

Cell size had no effect on 'Genesis' watermelon production in either year, nor were there any cell size $x$ transplant age interactions (Table 1 ). However, transplant age did influence yield during 1997. Six-week-old transplants produced more marketable fruits than 4- or 8-week-old transplants the first harvest of 1997 (Table 2). The increased number of fruits translated into an increase of total weight harvested. No fruit number differences were observed among treatment combinations at subsequent harvests. Total number of fruit produced by 6 week-old transplants over the course of the 1997 experiment was higher than 4-or 8-week-old transplants which led to a difference in total yield between 4- and 6-week-old transplants (Table 1). Differences in seedling stand loss may have affected yield, as there were fewer 6-week-old transplants lost in the first $28 \mathrm{~d}$ after planting. Incidence of hollowheart was negligible for 'Genesis' and soluble solid content (mean 11.8\% soluble solids) showed no response to any treatment combination during the 1997 or 1998 growing season. In 1998, no differences in measured parameters were noted for the different transplant ages for 'Genesis'.

No significant difference due to transplant age, cell size, or their interaction was seen for 'Ferrari' diploid 
Table 1. Total yield of 'Ferrari' diploid and 'Genesis' triploid watermelon grown for transplanting in varying cell sizes and ages.

\begin{tabular}{|c|c|c|c|c|}
\hline \multirow{3}{*}{$\begin{array}{l}\text { Cell size } \\
{\left[\operatorname{inch}^{3}\left(\mathrm{~cm}^{3}\right)\right]}\end{array}$} & \multicolumn{4}{|c|}{ Yield $(1 \mathrm{~b} / \text { acre })^{z, y}$} \\
\hline & \multicolumn{4}{|c|}{ Age (weeks) } \\
\hline & 4 & 6 & 8 & Mean \\
\hline & \multicolumn{4}{|c|}{ Ferrari (1997) } \\
\hline $1.5(25)$ & $40000 \mathrm{a}$ & $34200 \mathrm{a}$ & $47180 \mathrm{a}$ & $40460 \mathrm{~A}$ \\
\hline $3.4(56)$ & $28440 \mathrm{a}$ & $41200 \mathrm{a}$ & $36840 \mathrm{a}$ & $35494 \mathrm{~A}$ \\
\hline $7.9(130)$ & 33740 a & $33500 \mathrm{a}$ & $32850 \mathrm{a}$ & $33366 \mathrm{~A}$ \\
\hline \multirow[t]{2}{*}{ Mean } & $34060 \mathrm{~A}$ & $36300 \mathrm{~A}$ & $38954 \mathrm{~A}$ & \\
\hline & \multicolumn{4}{|c|}{ Ferrari (1998) } \\
\hline 1.5 & $53660 \mathrm{a}$ & $47480 \mathrm{a}$ & $61400 \mathrm{a}$ & $54180 \mathrm{~A}$ \\
\hline 3.4 & $36100 \mathrm{a}$ & $30960 \mathrm{a}$ & $35520 \mathrm{a}$ & $34194 \mathrm{~A}$ \\
\hline 7.9 & $35920 \mathrm{a}$ & $49040 \mathrm{a}$ & $37140 \mathrm{a}$ & $40700 \mathrm{~A}$ \\
\hline \multirow[t]{2}{*}{ Mean } & $41894 \mathrm{~A}$ & $42494 \mathrm{~A}$ & $44686 \mathrm{~A}$ & \\
\hline & \multicolumn{4}{|c|}{ Genesis (1997) } \\
\hline 1.5 & $35000 \mathrm{a}$ & $45480 \mathrm{a}$ & 37060 a & $39180 \mathrm{~A}$ \\
\hline 3.4 & $31960 \mathrm{a}$ & $48000 \mathrm{a}$ & $36500 \mathrm{a}$ & $38820 \mathrm{~A}$ \\
\hline 7.9 & $275200 \mathrm{a}$ & $35020 \mathrm{a}$ & $30840 \mathrm{a}$ & $21026 \mathrm{~A}$ \\
\hline \multirow[t]{2}{*}{ Mean } & $31494 \mathrm{~B}$ & $42834 \mathrm{~A}$ & $34800 \mathrm{AB}$ & \\
\hline & \multicolumn{4}{|c|}{ Genesis (1998) } \\
\hline 1.5 & $28960 \mathrm{a}$ & $38960 \mathrm{a}$ & $38060 \mathrm{a}$ & $35326 \mathrm{~A}$ \\
\hline 3.4 & $24120 \mathrm{a}$ & $31580 \mathrm{a}$ & $35860 \mathrm{a}$ & $30520 \mathrm{~A}$ \\
\hline 7.9 & $18000 \mathrm{a}$ & $20580 \mathrm{a}$ & $24500 \mathrm{a}$ & $21026 \mathrm{~A}$ \\
\hline Mean & $23694 \mathrm{~A}$ & $30374 \mathrm{~A}$ & $32806 \mathrm{~A}$ & \\
\hline
\end{tabular}

${ }^{\mathrm{z}} 1 \mathrm{lb} /$ acre $=1.12 \mathrm{~kg} \cdot \mathrm{ha}^{-1}$

y Mean separation of transplant age and cell size variable (capital letters) and their interactions (lower case letters) by $\operatorname{LSD}(P<0.05)$

Table 2. Effect of transplant age on yield components of 'Genesis' triploid watermelon in 1997.

\begin{tabular}{llrlll}
\hline \multirow{2}{*}{$\begin{array}{l}\text { Transplant } \\
\text { age }\end{array}$} & \multicolumn{2}{c}{ Early yield } & & \multicolumn{2}{c}{ Total yield } \\
\cline { 2 - 3 } (weeks) & $\begin{array}{l}\text { No./ } \\
\text { acre }\end{array}$ & $\begin{array}{c}\text { Wt } \\
(\mathbf{l b} / \mathbf{a c r e})^{\mathbf{y}}\end{array}$ & & $\begin{array}{l}\text { No./ } \\
\text { acre }\end{array}$ & $\begin{array}{c}\text { Wt } \\
\text { (1b/acre) }\end{array}$ \\
\hline 4 & $648 \mathrm{~b}^{\mathrm{z}}$ & $7314 \mathrm{~b}$ & & $2754 \mathrm{~b}$ & $31494 \mathrm{~b}$ \\
6 & $972 \mathrm{a}$ & $11596 \mathrm{a}$ & & $3564 \mathrm{a}$ & $42834 \mathrm{a}$ \\
8 & $728 \mathrm{~b}$ & $7670 \mathrm{~b}$ & & $2998 \mathrm{~b}$ & $34800 \mathrm{ab}$
\end{tabular}

${ }^{\mathrm{z}} 1 \mathrm{lb} /$ acre $=1.12 \mathrm{~kg} \cdot \mathrm{ha}^{-1}$

${ }^{y}$ Means followed by same letter are not significantly different. Separation by LSD $(P<0.05)$.

watermelon yield during either year (Table 1). Incidence of hollowheart was negligible and soluble solid content (mean $11.0 \%$ soluble solids) showed no response to any treatment combination during the 1997 or 1998 growing season.

Transplant age has shown no effect on yields of watermelon and other cucurbit crops; watermelon (Vavrina et al., 1990, 1993), squash (Cucurbita pepo L.) (NeSmith, 1993), and muskmelon (Cucumis melo L.) (NeSmith, 1994). The results from the current experiment with the triplod watermelon 'Genesis' were in contrast to these earlier findings. However, emergence of 'Genesis' in the greenhouse was very erratic, occurring over 2 weeks whereas, emergence of 'Ferrari' oc- curred within $5 \mathrm{~d}$ of seeding. Therefore, actual seedling age varied greatly for 'Genesis' within each seeding date. For example, some transplants which were taken to be 4 weeks old could have only been emerged for 2 weeks. Scarification and hydrogen peroxide treatments (Duval and NeSmith, 1998a, 1998b) improve germination, emergence, and seedling uniformity of 'Genesis'. Removing the variability in transplant age of 'Genesis' could minimize the effect of age on transplant performance.

Results for the cell size effect on total yield are contradictory to some previous findings. Hall (1989) and Liu and Latimer (1995) both reported increasing cell size increased total yields. However, Vavrina et al. (1993) showed no differences in total yield due to cell size. Current literature concerning cell size effects is filled with contradictory evidence on performance of transplants within species and cultivars $(\mathrm{NeSmith}$ and Duval, 1998), therefore, this is not uncommon.

The results from this experiment suggest most of the problems associated with the establishment of 'Genesis' watermelon occur in the greenhouse. Once transplants are moved to the field, 'Genesis' watermelons require no more care than a diploid cultivar, with the notable exception of needing a pollinizer. 'Genesis' transplants seeded in 3.4 inch $^{3}\left(56 \mathrm{~cm}^{3}\right)$ produced a large number of viable transplants, also it was the easiest to handle in the field. Transplants grown in a larger volume cell were difficult to pull out of the transplant flats, and left large amounts of roots behind. Plants grown in the smallest volume were difficult to handle and were easily buried when transplanted.

\section{Literature cited}

Damato, G., L. Trotta, and A. Elia. 1994. Cell size, transplant age and cultivar effects on timing of field production of broccoli (Brassica oleracea var. Italica Plenck) for processing. Acta Hort. 371:53-57

Duval, J.R. and D.S. NeSmith. 1998a. Influence of mechanical scarification on emergence and seed coat adherence of 'Genesis' triploid watermelon. HortScience 33:597 (abstr.).

Duval, J.R. and D.S. NeSmith. 1998b. Germination response of 'Genesis' triploid watermelon [Citrullus lanatus (Thunb.) Matsum and Nakai] to hydrogen peroxide and seed coat alteration. HortScience 33:545 (Abstr.)

Hall, M.R. 1989. Cell size of seedling containers influences early vine growth and yield of transplanted watermelon. HortScience 23:771-773.

Harmon, R., L.A. Weston, and T. Jones. 1991. Effect of root cell size and transplant age on yield of transplanted eggplant. HortScience 26:689 (Abstr.)

Jones, R.T., L.A. Weston, and R. Harmon. 1991. Effect of root cell size and transplant age on cole crop yields. HortScience 26:688 (abstr.).

Kratky, B.A., J.K. Wang, and K. Kubjiri. 1982. Effect of container size, transplant age and plant spacing on Chinese cabbage. J. Amer. Soc. Hort. Sci. 107:345-347.

Liptay, A. 1987. Field survival and estab- 
lishment of tomato transplants of various age and size. Acta Hort. 220:203-209.

Liu, A. and J.G. Latimer. 1995. Root cell volume in the planter flat affects watermelon seedling development and fruit yield. HortScience 30:242-246.

Maynard, D.N. 1997. Triploid watermelon transplant production. 8th Intl. Symp. Timing of Field Prod. in Veg. Crops. Bari, Italy. Oct. 1997.

NeSmith, D.S. 1993. Transplant age influences summer squash growth and yield. HortScience 28:618-620.

NeSmith, D.S. 1994. Transplant age has little influence on yield of muskmelon ( $\mathrm{Cu}$ cumis melo L.). HortScience 29:916.

NeSmith, D.S. and J.R. Duval. 1998. Transplant production and performance: The effect of container size. Hort Technology $8(4): 495-498$.

Olson, S.M. and S.J. Locascio. 1990. Influence of transplant age and container size on broccoli production. HortScience 25:1120.

SAS Institute. 1990. SAS user's guide: Statistics. 6th ed. SAS Inst., Cary, N.C.

Vavrina, C.S. and K. Armbrester. 1991. Effect of transplant age and cell size on pepper production. S.W. Fla. Res. Ext. Ctr. Res. Rpt. IMM 91-8.

Vavrina, C.S., K. Armbrester, and T.B. Cole. 1990. Watermelon production as influenced by transplant age. Proc. Fla. State Hort. Soc. 103:94-96.

Vavrina, C.S., S. Olson, and J.A. Cornell. 1993. Watermelon transplant age: Influence on fruit yield. HortScience 28:789790

Weston, L.A. 1988. Effect of flat cell size, transplant age, and production site on growth and yield of pepper transplants. HortScience 22:709-711 